Article

\title{
Innovative or Not? The Effects of Consumer Perceived Value on Purchase Intentions for the Palace Museum's Cultural and Creative Products
}

\author{
Zhao Li ${ }^{1}$, Shujin Shu ${ }^{2}$, Jun Shao ${ }^{2, *} \mathbb{C}$, Elizabeth Booth ${ }^{3}$ and Alastair M. Morrison ${ }^{3}(\mathbb{C}$ \\ 1 College of Urban and Environmental Science, Peking University, Beijing 100871, China; zhao.li@pku.edu.cn \\ 2 School of Landscape Architecture, Beijing Forestry University, Beijing 100083, China; \\ sueshushujin@bjfu.edu.cn \\ 3 Department of Marketing, Events and Tourism, Business School, University of Greenwich, \\ London SE10 9LS, UK; e.booth@greenwich.ac.uk (E.B.); a.morrison@greenwich.ac.uk (A.M.M.) \\ * Correspondence: ninashaojun@bjfu.edu.cn
}

Citation: Li, Z.; Shu, S.; Shao, J.; Booth, E.; Morrison, A.M. Innovative or Not? The Effects of Consumer Perceived Value on Purchase Intentions for the Palace Museum's Cultural and Creative Products. Sustainability 2021, 13, 2412. https://doi.org/10.3390/su13042412

Academic Editor: Deborah Agostino

Received: 17 January 2021

Accepted: 18 February 2021

Published: 23 February 2021

Publisher's Note: MDPI stays neutral with regard to jurisdictional claims in published maps and institutional affiliations.

Copyright: (c) 2021 by the authors. Licensee MDPI, Basel, Switzerland. This article is an open access article distributed under the terms and conditions of the Creative Commons Attribution (CC BY) license (https:// creativecommons.org/licenses/by/ $4.0 /)$.

\begin{abstract}
A museum's core activities traditionally focus on such areas as collections' care, exhibitions and scholarship. Income generation, including retail activities, is considered secondary. Academic research into museums' merchandise, especially into the perceived value and purchase intentions, is limited. Drawing on literature embracing both core museum functions and marketing, this research, based on the Palace Museum in Beijing, China, explores the impact of the perceived value of a museum's cultural and creative products on purchase intentions. Combining the results of indepth interviews with museum visitors and experts, this study defines a construct composed of six perceived value dimensions, namely quality, social, price, innovation, educational, and experience values. A relationship model of perceived value and purchase intentions is proposed. Some 346 valid survey responses were obtained by distributing a questionnaire online and on-site at the Palace Museum, and hypotheses were tested by structural equation modelling. Results showed that innovation and experience values have a significant positive effect on purchase intentions, while quality, social, price, and educational values had no significant influence on purchase intentions. This research outlines feasible strategies and actions for the development of cultural and creative products at museums that have a strong tourism role.
\end{abstract}

Keywords: innovation value; perceived value; purchase intentions; virtual museums; cultural and creative products; Palace Museum (Forbidden City); online purchasing

\section{Introduction}

In order to ensure their survival and sustainability, museums are looking for innovative solutions and innovative strategies, as there is limited financial support from governments. In particular, during the COVID-19 pandemic, museum exhibitions and activities, like those of the Italian state museums [1], are being moved from offline to online. The roles of museums are now in constant evolution, adopting greater social and marketing orientations depending on need, opportunity, and the degree to which collections offer scope for creative product interpretation. A museum is defined by the International Council of Museums (ICOM) as a 'non-profit, permanent institution in the service of society and its development, open to the public, which acquires, conserves, researches, communicates and exhibits the tangible and intangible heritage of humanity and its environment for the purposes of education, study and enjoyment' [2]. The scholarly or curatorial role of a museum is core, with income generation a supporting or secondary consideration. Thus, there are ethical, social, and cultural tensions inherent in engagement with the market by trading goods for sale [3]. For most of the 20th century, a museum was regarded as an institution that collects, preserves, researches, interprets, and displays social material culture [4]. By the end of the 20th century, market-oriented ideology emphasized the importance of revenue generation 
and brought new expectations to museums [5]. Coupled with the reduction of government funds, museums were under pressure like enterprises [6]. In this context, museums began to generate revenue in a variety of ways, with cultural products being regarded as one of the important options for museums to generate revenue [7]. By selling cultural products, a museum not only solves its non-profit funding issues to improve its current environment and operating conditions [8] but also positions these products to convey its cultural and historical values to tourists [9]. Current debates revolve around the idea of the museum as a "cultural shop" ([5,10-12]), a place where visitors come to enjoy, participate in, or consume a variety of educational and cultural products and merchandise.

Visitors arrive at virtual museums online and in person [13] with a variety of motivations and expectations [14]; this is as true of their engagement with the museum shop [6] as with the exhibits on display. Tosun et al. [15] point out that shopping is an important component of travel, and Timothy [16] states that tourism and shopping have common linkages. However, there are continuing discussions around the meaning and purpose of trading museums, which are essentially repositories of shared heritage. Investigating public engagement with retail products involves considering aspects of a museum's core function and identity as well as the usual dimensions involved in measuring customers' perceptions and attitudes. Mottner and Ford [7] investigated performance indicators for museum retail based on educational, interpretive, and quality criteria. In this research, the authors embrace the changing milieu of the museum in 2020 to understand the perceptions of customers in the environment of a museum, which can be considered to possess some of the dimensions of the cultural shop.

A National Audit Office [17] report on the trading activities of the British nationally sponsored museums identifies key trading methods as including e-commerce, licensing, catering, retail, reproduction and photograph rights, mail order, and venue hire. In addition, museum funding can come from a variety of sources including donations and memberships, corporate sponsorship, and national and local government grants. One of the foremost examples in the UK, the Victoria and Albert Museum, has a total income base of $£ 32.5 \mathrm{~m}$ including admissions, trading, and donated objects. In 2017, the Palace Museum (aka the Forbidden City), one of China's major tourism attractions and the leader among Chinese museums, had sales of cultural and creative products of CNY 1.5 billion [18]. The number of consumers visiting the museum on Tmall.com, the largest business-to-consumer retail platform in Asia, reached 60 million and is already three times that of in person visitors [19]. Up to August 28, 2018, among the top ten museums with the highest sales on Tmall, the Palace Museum's cultural and creative store ranked first with CNY 242 million [19], demonstrating the power of the digital platforms to expand cultural shopping experiences beyond museum walls. Thousands of museums in China are exploring how to entice people to buy their cultural and creative products, and in so doing to better serve tourists and local residents. Visitors tend to make purchase decisions based on the perceived value of the products or services provided by suppliers. Therefore, in order to stand out from their competitors, it is essential for museums to know how to highlight the perceived value of their products and services in appropriate and visible ways.

Why then do visitors buy the cultural and creative souvenirs sold by museums? What are the specific dimensions of consumers' perceived value of cultural and creative products? What is the relationship between the dimensions of perceived value and purchase intentions? To answer these questions, this research proposed a perceived value construct suitable for the context of tourism-oriented museums and their cultural and creative products based on prior works in consumer behavior. The innovative, educational, and experiential values of museums' cultural and creative goods and paid services are attracting greater attention. The components of consumers' perceived value with respect to these products and services need to be the focus of more intensive research. This more granular analysis of perceived value towards museum cultural goods and services will increase knowledge and understanding of purchase intentions. Theoretically, a valuable contribu- 
tion of this research was specifying the dimensions (educational, experience, innovation, price, quality, and social) of retail products for sale in museums.

\section{The Palace Museum and Its Cultural and Creative Products}

The Palace Museum was chosen as a case example since it is the most visited heritage tourism attraction in China and owns the most popular online stores in Asia with more than 10 million fans. It acts as a model whose initiatives tend to be imitated by hundreds of other heritage attractions in the country. Established in 1925, the current facility of the Palace Museum was built on the palaces of the Forbidden City and exhibits collections from the Ming and Qing Dynasties. A World Heritage Site since 1987, the Forbidden City was the official residence of Chinese Emperors from 1420 until 1911. As China's supreme center of power for more than five centuries, it is an invaluable historical testament to Chinese civilization during the Ming and Qing dynasties, with its landscaped gardens and a huge complex of buildings housing furniture and works of art [20].

\subsection{History of the Forbidden City (Palace Museum)}

The Forbidden City exhibits the interchange of human values throughout the history of Beijing, which was established according to the classic "three-tier city wall (imperial, inner, and outer)" layout system for a traditional Chinese capital. As almost all of the inner city and outer city of Beijing vanished during city reconstruction, the Forbidden City is well conserved and is a major geographical landmark of Beijing.

Due to its unique geographic location and strategic value, Beijing and its predecessors witnessed the historic stages of China. The origin of Beijing can be traced back to the city of Ji in the Western Zhou Dynasty (1046 B.C.-771 B.C.). Since the middle of the Tang Dynasty (618-907), the ethnic groups beyond the Great Wall began to move southward one after another for more than eight centuries. In the end, Beijing replaced Chang'an as the political center of a unified China. Its capital history began with the rise of Liao Dynasty (907-1125). It was renamed Nanjing as the southern capital of the Liao Dynasty by the nomadic Khitan people expanding southward from beyond the Great Wall. During the Jin Dynasty (1115-1234), the city was expanded with reference to Bianliang, the capital of the Northern Song Dynasty (960-1127) in Central China. It was renamed Zhongdu and made the formal capital of Jin Dynasty in 1153. As shown in Figure 1, Kublai Khan built the city of Dadu near the detached palace in the northeastern suburbs of Zhongdu, which was destroyed by war. Dadu became the capital of the Mongol-led Yuan dynasty (1279-1368), when all of China was ruled for the first time. New aqueducts were built to introduce more water from mountain springs into Dadu. Benefitting from the abundant water supply, boats from the Grand Canal could be pulled into the city and the wharf was developed into the largest market within the capital. Wider lakes in the city also created a splendid landscape. In 1368, after the Ming army captured Dadu, the north city wall was moved 2.5 kilometers south for defense. In 1403, the Ming Dynasty decided to move its capital northward to Beijing and began to build city walls and palaces, preparing for its new capital. During this period, one of the most iconic historical buildings, the Forbidden City was built. The southern wall of the city was moved one kilometer to the south as well. After the middle of the Ming Dynasty, due to the increase of population and the need for defense, the outer city was built in 1553, and the Temple of Heaven and other buildings were included in the city (Figure 1) [21,22]. Since then, the Forbidden City, as the core of the central axis extending $7.8 \mathrm{~km}$, became one the most obvious symbols of Beijing.

\subsection{Palace Museum Cultural and Creative Products}

The Palace Museum has rich treasures of ancient objects, so that it is an important window for spreading Chinese culture. In 2018, the museum received over 17.5 million visitors [23]. People born in the 1980s and 1990s are the main visitor groups to the Palace Museum [23]. Meanwhile, online consumers of cultural and creative products are relatively 
younger, with more than half born in the 1990s, of which the highest proportion were born after 1995 [19].

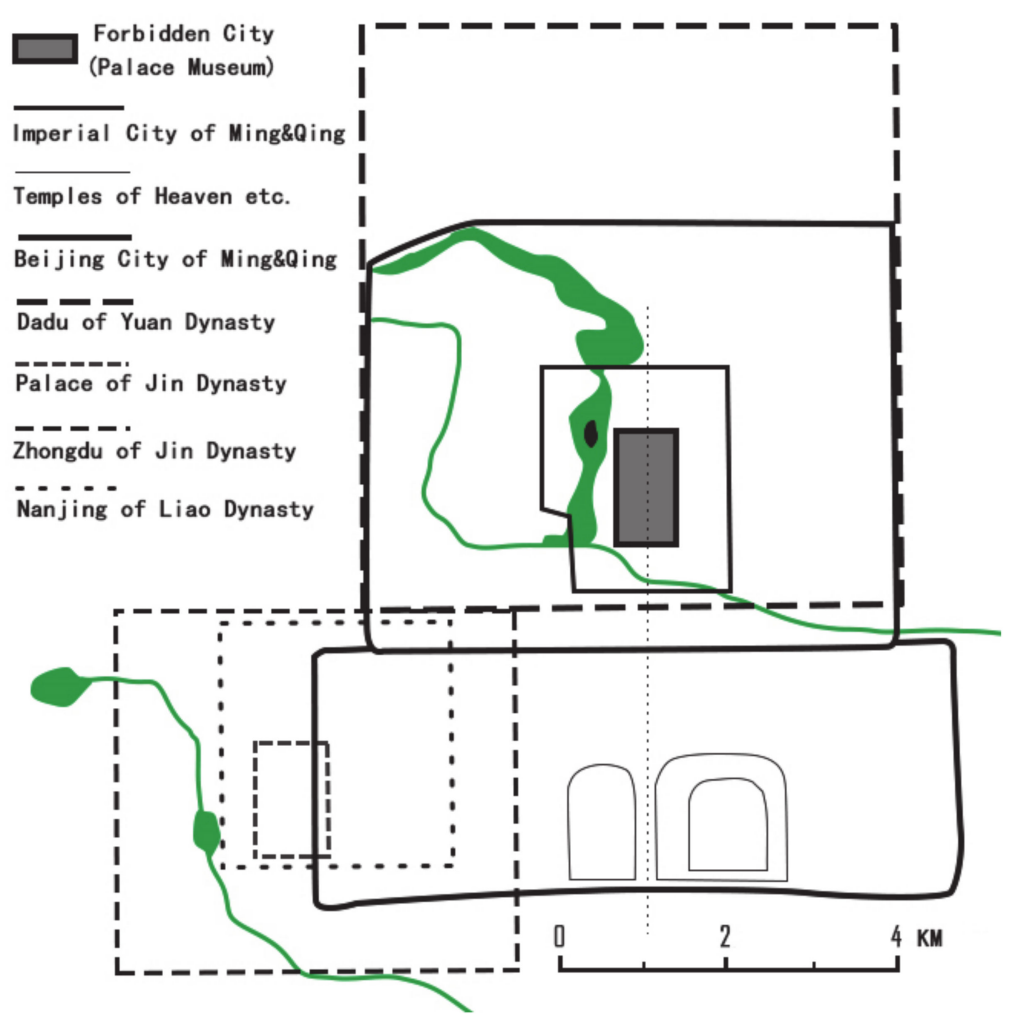

Figure 1. The Change of City Walls of Beijing through Liao, Jin, Yuan, Ming, and Qing Dynasties.

As early as 2008, cultural products were sold in the Palace Museum. However, due to their high prices and lack of innovativeness, the annual sales revenues were only about CNY 150 million until 2012 [24]. From 2013, the Palace Museum began to transform itself and developed many popular cultural and creative products by integrating elements of cultural relics and traditional culture. The Palace Museum has become a super online celebrity through a series of digital marketing campaigns since 2014. Sales of cultural products in the Palace Museum increased from CNY 600 million in 2013 to CNY 1.5 billion in 2017 [18]. A large part of the cultural and creative income of the Museum is used to organize public education activities. For example, more than 60,000 educational activities were held in 2018, including those held in overseas countries such as Malta, Singapore, Thailand, and Australia [25].

At present, the Palace Museum's cultural and creative products are sold both online and offline. In terms of online shopping, in addition to Palace Museum Taobao at taboao.com and The Palace Museum's Flagship Store of Cultural and Creative Products (PMFSCCP) at tmall.com, there are also The Palace Museum's Official Flagship Store selling tickets and The Palace Museum's Publications selling publication works like calligraphy and paintings at tmall.com. In terms of brick and mortar stores, the Museum has many traditional gift shops, which are located both inside and outside the Museum. In February 2018, the Museum created a pop-up store, a new kind of short-term shop used by many famous fashion brands to attract their fans.

During the COVID-19 epidemic, from 25 January to 30 April 2020, the Palace Museum closed its on-site business and moved operations to online like many other cultural institutions. The museum used social media to carry out "cloud exhibitions", "cloud lectures" and educational programs, e.g., "National treasures" which invited celebrities to participate. Online flagship stores' business transactions were not interrupted. They continued to 
promote new cultural and creative products by the "Something new is coming in the Palace Museum" program via social media platforms and TV channels.

\section{Theoretical Background and Hypotheses}

\subsection{Branding and Integrating Marketing Communication of Musuems}

The branding and integrated marketing communications (IMC) of museums have been neglected and are often controversial [26]. However, in practical terms, museum marketers should be encouraged to adopt branding strategies to ensure sustainability $[26,27]$ as branding is a structural element of survivability [26] and has provided great economic and social benefits for museums [26-29], especially in today's persistent economic instability [26]. According to the definition of non-profit organization branding given by Hankinson and Rochester [30], museum branding can be defined as the intentional and active management of a series of brand perceptions (tangible and intangible) in order to convey consistent and coherent information to stakeholders. Belenioti and Vassiliadis [27] identified that branding has the following development benefits for non-profit organizations, including museums. First, successful brand marketing can make non-profit organizations gain strong brand personality, and then cultivate brand awareness and establish trust and customer loyalty $[27,31]$. Second, a strong nonprofit brand can help museums achieve fundraising goals by attracting donors and generating support [30-32]. Third, a strong brand can strengthen contact with stakeholders through the consistency and coherence that is achieved in branding [32,33]. All of these contribute to the sustainability and management of the organization.

IMC tools are the core of the brand equity of museums [27,34,35]. In particular, the rise of social media has completely changed the way museums communicate $[29,36,37]$. Now these platforms are becoming the ideal, cost-effective, and interactive communication tools for museums given the high consumer participation provided through electronic word of mouth (eWOM) and network interaction [27,37]. Using IMC tools, especially social media marketing, the experience and communication by museums, as well as the learning processes and participation of visitors, can be significantly improved [29]. Moreover, social media are beneficial to museum brand equity, visitor satisfaction, and engagement [34]. Applying IMC and social media is expected to increase museum brand equity, thereby increasing brand loyalty and the repurchase willingness of visitors [35,38]. However, museums have not fully utilized the potential of social media, and communication with visitors is still relatively backward [36,38-41]. The shortage of resources, difficulties in measuring the cost-benefit ratio, and performance of media activities are the main factors that hinder the further use of social media by cultural institutions [39].

Like traditional profit-making enterprises, the ultimate vision of branding museums is to create differences by conveying unique identities in consumers' minds [27]. The focus of museum marketing and branding should be carefully combined with commercialization initiatives and traditional curatorial perspectives so as to enhance visitors' museum experiences and enhance the identity, image, and recognition of museums [26]. Museum cultural and creative products can be seen as a part of the practice of IMC. Thus, the related literature is discussed in the next section.

\subsection{Cultural and Creative Products in Museums}

As early as the 1950s, Western museum shops began selling certain ordinary commodities [42]. The types and styles of museum products have eventually become more diversified. To distinguish them from typical tourism souvenirs, scholars have studied the attributes, functions, and development principles of cultural creative products in museums. "Museum cultural and creative products" is a concept that has only been proposed in recent years by museums and the cultural and creative industry, and it appears more often in Chinese and Taiwanese literature. In the existing literature, the term is found expressed in multiple forms, such as "museum cultural and creative products" [43], "museum cultural products" ([42,44,45]), "museum cultural creative merchandise" [46], and "museum 
souvenirs" ([47-49]). In this research, these similar concepts are collectively named as "museum cultural and creative products" and refer to creative and unique cultural products sold by museums.

Chen [50] suggested that museum cultural and creative products have communication, economic, aesthetic, practical, collection, and emotional values, and the seven principles of culture, aesthetics, practicality, interest, uniqueness, seriality and diversity should be followed in their development process. In the experience era, one observable museum trend is the growing attention to sociable, recreational, and participatory experiences [51]. Experiential products and services are becoming more popular; for example, the Indianapolis Museum of Art has developed a number of participatory projects based on simulation and technology, which have received positive visitor responses [52].

More scholars are introducing consumer behavior theory into the field of museum product development. Chiou and Wang [43], based upon the Tamsui Historical Museum (Taipei, Taiwan), divided consumers' purchasing motives into three parts based on the genetic algorithm theory: intellectual genes (museum features, heritage beauty, cultural profundity, and indigenous customs); rational genes (practicality, enjoyment, creativity, storyoriented, safety, and reasonable prices); and emotional genes (feeling touched, supporting the museum, and recommendations to relatives and friends). Through a questionnaire survey, they found that most people considered intellectual genes, followed by rational and then emotional genes. This research provided a fresh perspective for optimizing the cultural and creative brand design of museums. Lin et al. [45] advanced six criteria for museum visitors' intentions to purchase cultural products by using the decision-making trial and evaluation laboratory (DEMATEL) technique. These were culture, experience, price, function, uniqueness, and design, of which culture and experience were the core influential criteria. Ye and Huang [53] recommended the development of museum products and services must incorporate the feelings of consumers. Different visitor groups have varying perceptual characteristics, and products should be designed according to specific consumer consumption preferences. Tu, Liu and Cui [54] also pointed out that when choosing museum cultural creative products, consumers attach great importance to factors such as "cultural connotation" and "unique creativity".

In addition, in view of the relationship between the products of museum stores and museum collections [7], museum cultural and creative products are regarded as important cultural carriers of museum collections. In other words, museum cultural and creative products can be regarded as an extension of the educational function of museums [45], indicating that the products may have certain educational value. Kotler [51] believes that it is a trend for museums to provide social, entertainment, and participation experiences, which suggests that consumers may consider the value of "experiences" when buying cultural products. From this research literature, it can be seen that cultural, creative, educational, and experiential values are important attributes of museum cultural and creative products.

\subsection{Customer Perceived Value and Purchase Intentions}

The concept of customers' perceived value first appeared in Porter's Competitive Advantage [55]. Although he did not clearly define the concept, Porter provided the direction for later research. The research on customer perceived value gradually emerged, and scholars put forward their own views on it. Zeithaml [56] suggested that perceived value can be regarded as a "consumer's overall assessment of the utility of a product (or service) based on perceptions of what is received and what is given". Woodruff [57] believed that perceived value was "a customer's perceived preference for and evaluation of those product attributes, attribute performance, and consequences arising from use that facilitate (or block) achieving the customer's goal and purposes in use situations".

Perceived product value has tangible and intangible dimensions [58]. Sheth, Newman, and Gross [59] suggested that it can be divided into five value components, namely functional, emotional, social, epistemic, and conditional. The components impact consumer 
choice behavior at the buying decision level (to buy or not to buy), product level (buy product A or product B), and brand level (buy brand A or brand B). These results laid a foundation for later research. Sweeney and Soutar [60] proposed four dimensions of consumer's perceived value of durable goods: functional quality, functional price, social value, and emotional value. Moreover, they built specific measurement scales for perceived value, which have been widely used by many subsequent scholars $([61,62])$. Although customer perceived value studies have covered a wide range of industries and different types of products, such as hospitality [63], luxury goods [64], tourism products [61], wetland parks [65] and so on, they have not yet investigated museums' cultural and creative products.

Customers' purchase intentions represent customers' willingness to buy products from particular shops or retailers ([66,67]). Research on the relationship between consumer perceived value and purchase intentions can be divided into two categories. One category regards perceived value as a single-dimensional variable and studies the impact of perceived value and other variables (such as perceived cost, perceived return, etc.) on purchase intention ([68-71]). For example, Chen and Chang [68] discussed the relationship between the perceived value, perceived risk, trust, and willingness to buy green products and found that the perceived value of green products had a positive effect on purchase intentions. The second category uses purchase intentions as a multi-dimensional variable and examines the impact of perceived value on purchase intentions ([62,72,73]). For example, Wang [64] divided consumers' perceived value of snack foods into four dimensions, which were quality, price, emotional, and social value. The study found that perceived price and emotional value had positive impacts on purchase intentions, while quality and social values had no significant effect. Wood and Scheer [73], for example, added perceptual risk to the perceived value model, arguing that perceived risk and perceived value affected consumers' willingness to purchase. This research positioned purchase intentions as an outcome variable in exploring the relationship between multi-dimensional perceived value and purchase intentions.

In summary, researchers generally agree that perceived value has a positive effect on purchase intentions. However, due to the differences in product/service attributes and consumption environments, different dimensions of perceived value have varying degrees of influence on purchase intentions.

\subsection{Research Hypotheses}

Considering that no research has proposed specific dimensions of the perceived value of museum cultural and creative products, based on the literature review, this research combines the results of in-depth interviews and expert consultations to condense the perceived value dimensions of cultural and creative products in tourism-oriented museums. In-depth interviews were conducted from February to March in 2018 with 13 tourists who visited the Palace Museum and purchased its cultural and creative products. The interviews collected tourists' opinions on the features of the cultural and creative products of the Palace Museum, reasons for purchases, and factors affecting purchase decisions. Expert consultations were held on 5 March, 21 March, and 4 April 2018 with a museum expert on issues such as the division of perceived value dimensions and the design of scale items.

It was confirmed that the Palace Museum's cultural and creative products possessed the four dimensions of durable consumer goods proposed by Sweeney and Soutar [60], namely quality, price value, social values, and emotional values. However, it is worth noting that, in terms of the dimension of perceived emotional value, the interview found that this was caused by the unique attributes of the museum's cultural and creative products, namely, the innovation value and educational values. Therefore, this research separated these two dimensions. In addition, Kotler [51]'s experiential dimension was confirmed by the results of the in-depth interviews with tourists and expert consultations. Therefore, this research proposed a six-dimensional value framework for the museum's cultural and 
creative products, namely quality, social, price, innovation, educational, and experiential values.

Previous research suggests that consumer perceived value leads to purchase intentions (e.g., [63,68,72-74]). The results of the in-depth interviews confirmed that the quality, social, and price values of the Palace Museum's cultural and creative products were likely to enhance their value proposition. Thus, the first three hypotheses were proposed as follows:

Hypothesis 1 (H1): The quality value of the Palace Museum's cultural and creative products has a positive effect on consumer purchase intentions.

Hypothesis 2 (H2): The social value of the Palace Museum's cultural and creative products has a positive effect on consumer purchase intentions.

Hypothesis 3 (H3): The price value of the Palace Museum's cultural and creative products has a positive effect on consumer purchase intentions.

Innovation value affects consumer willingness to purchase cultural and creative products $([45,54])$. According to the in-depth interviews, Palace Museum visitors will buy its cultural and creative products if they feel that items are creatively designed. Moreover, educational value is significant for museum merchandise ([11,51]). As cultural and creative products of museums have educational functions [45], some respondents and the expert who were interviewed confirmed that visitors are attracted by products' educational values and are inclined to buy them. In addition to products directly related to the museum's buildings and collections, intangible products (e.g., VR video, lectures, music performances) reflecting the historical knowledge and meaning carried by the Forbidden City are very popular. At present, museums are actively providing various experiences to attract tourists ([11,51]). Existing research (e.g., [45]) and the interviews conducted indicated that visitors may consider the value of "experience" when purchasing cultural and creative products. Recognizing the unique dimensions of these products and their impacts on purchase intentions at museums, the following three hypotheses were proposed:

Hypothesis 4 (H4): The innovation value of the Palace Museum's cultural and creative products has a positive effect on consumer purchase intentions.

Hypothesis 5 (H5): The educational value of the Palace Museum's cultural and creative products has a positive effect on consumer purchase intentions.

Hypothesis 6 (H6): The experiential value of the Palace Museum's cultural and creative products has a positive effect on consumer purchase intentions.

In summary, the conceptual relationship model and the six hypotheses are shown in Figure 2.

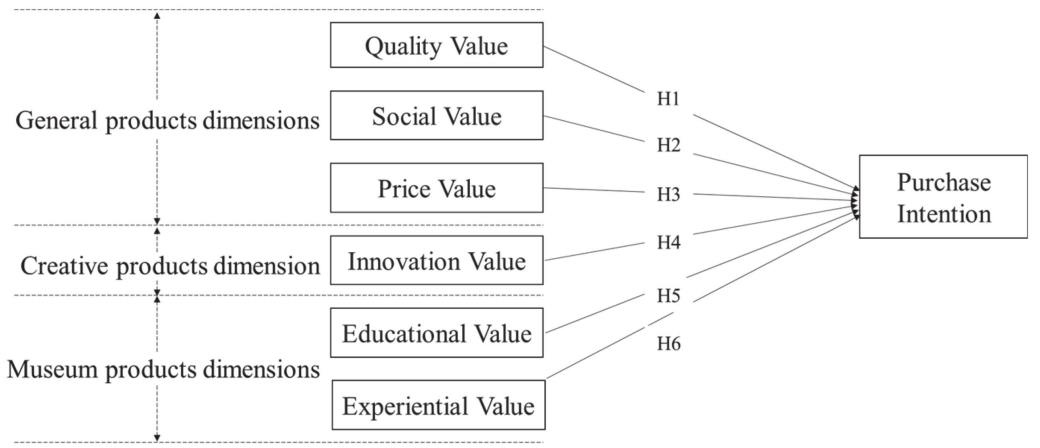

Figure 2. The Conceptual Model. 


\section{Methodology}

\subsection{Measurement}

A preliminary scale for the perceived value of cultural and creative products in tourism-oriented museums was first developed based on the literature review, in-depth interviews, and expert consultation. Then, in order to ensure the structural validity of the questionnaire measurement, the researchers distributed 44 questionnaires to tourists and museum experts. Thereafter, the expressions of the questionnaire measurement items were modified according to the feedback received. Specially, the perceived quality, social, and price values were adopted according to Sweeney and Soutar [60] and the in-depth interviews. Innovation value was based on the results of the in-depth interviews and consisted of four items. Educational value items were chosen with reference to Mottner and Ford [7], in-depth interviews, and expert consultation. Experience value items were selected referring to the results of Mathwick, Malhotra and Rigdon [75], Kotler [51], and expert consultation results.

The final questionnaire consisted of three main parts. Part 1 had filtering and classification questions, which asked respondents whether they knew about the Palace Museum's cultural and creative products and whether they had ever purchased them. Part 2 was the measurement of customer perceived value and purchase intentions with 28 items, which were measured by a 5-point Likert-type scale from "strongly disagree (1)" to "strongly agree (5)". Part 3 gathered respondents' demographic information with six items including age, gender, occupation, residence, educational background, and monthly income.

\subsection{Sampling}

The final questionnaires were distributed from April 6 to April 23, 2018 at the Palace Museum. All the respondents were Chinese domestic tourists. Residents of Beijing were excluded for this analysis as they did not qualify as tourists. The visitors were asked whether they knew about the Palace Museum's cultural and creative products and whether they were willing to complete the survey. If they answered these questions in the positive, they were asked to fill out a paper-and-pencil questionnaire under the guidance of the fieldwork team. A total of 465 questionnaires were collected. Some 346 forms were valid after deleting those with incomplete or insincere responses ( $74.4 \%$ response rate).

\subsection{Data Analysis}

First, an exploratory factor analysis (EFA) was used to determine the appropriate number of factors to be applied in the analysis, while Cronbach's alphas measure the reliability coefficients for each latent variable. Second, a confirmatory factor analysis (CFA) with maximum likelihood estimation was conducted to test the validity and reliability of the constructs of the measurement model, including composite reliability, convergent validity, and discriminant validity. Finally, structural equation modeling (SEM) was used to estimate all parameters and to verify the hypotheses. The EFA and the reliability analysis were conducted with SPSS 22.0 software and the CFA and SEM procedures were conducted with AMOSS 22.0 software.

\section{Results}

\subsection{Descriptive Statistics}

As shown in Table 1, some $70.5 \%$ of the respondents were female, and $66.5 \%$ were between the ages of 20 and 39. The largest income group was between CNY 1500 to CNY 3000 per month, and a very high proportion $(69.9 \%)$ was college graduates or students. The respondents, who were students or corporate staffed, account for $76.3 \%$ of the sample. 
Table 1. Demographic characteristics $(n=346)$.

\begin{tabular}{|c|c|c|c|c|c|}
\hline Variable & $n$ & $\%$ & Variable & $n$ & $\%$ \\
\hline \multicolumn{3}{|c|}{ Gender } & \multicolumn{3}{|l|}{ Age } \\
\hline Male & 102 & 29.5 & 19 years old and below & 32 & 9.2 \\
\hline Female & 244 & 70.5 & 20-29 years old & 230 & 66.5 \\
\hline \multicolumn{2}{|c|}{ Monthly income (CNY) } & & 30-39 years old & 61 & 17.6 \\
\hline$<1000$ & 34 & 9.8 & 40-49 years old & 17 & 4.9 \\
\hline $1000-1500$ & 51 & 14.7 & 50 years old and above & 6 & 1.7 \\
\hline $1500-3000$ & 71 & 20.5 & \multicolumn{3}{|l|}{ Occupation } \\
\hline $3000-5000$ & 58 & 16.8 & Student & 155 & 44.8 \\
\hline $5000-8000$ & 49 & 14.2 & Corporate staff & 109 & 31.5 \\
\hline $8000-10,000$ & 30 & 8.7 & Institutional staff & 29 & 8.4 \\
\hline$>10,000$ & 53 & 15.3 & Government official & 2 & 0.6 \\
\hline \multicolumn{3}{|c|}{ Educational level } & Individual industrial and commercial & & \\
\hline Junior high school and below & 6 & 1.7 & households & 15 & 4.3 \\
\hline High school & 21 & 6.1 & Freelancer & 24 & 6.9 \\
\hline University or college & 242 & 69.9 & Retired staff & 1 & 0.3 \\
\hline Graduate and above & 77 & 22.3 & other & 11 & 3.2 \\
\hline
\end{tabular}

As shown in Table 2, the quality, innovation, educational, and experience values earned the highest mean rankings, with innovation value scoring the most at 4.0. The mean rankings for social and price values of the Palace Museum's cultural and creative products were about 3.1. The mean for purchase intention was 3.65, indicating that respondents had a healthy willingness to buy cultural and creative products in the Palace Museum, which is consistent with the significant sales levels of products at the museum.

Table 2. Descriptive statistical analysis $(n=346)$.

\begin{tabular}{|c|c|c|c|c|c|c|c|}
\hline Variable & Mean & Variance & Items & Mean & Standard Deviation & Skewness & Kurtosis \\
\hline \multirow{4}{*}{ Quality value } & \multirow{4}{*}{3.78} & \multirow{4}{*}{0.46} & QV1 & 3.89 & 0.82 & -0.72 & 0.94 \\
\hline & & & QV2 & 3.82 & 0.78 & -0.34 & 0.22 \\
\hline & & & QV3 & 3.81 & 0.86 & -0.48 & 0.97 \\
\hline & & & QV4 & 3.60 & 0.81 & -0.09 & -0.31 \\
\hline \multirow{4}{*}{ Social value } & \multirow{4}{*}{3.12} & \multirow{4}{*}{0.72} & SV1 & 3.34 & 0.96 & 0.02 & -0.43 \\
\hline & & & SV2 & 3.32 & 1.03 & -0.05 & -0.42 \\
\hline & & & SV3 & 2.76 & 0.97 & 0.31 & 0.17 \\
\hline & & & SV4 & 3.06 & 1.02 & 0.06 & -0.44 \\
\hline \multirow{4}{*}{ Price value } & \multirow{4}{*}{3.15} & \multirow{4}{*}{0.70} & PV1 & 3.14 & 0.97 & -0.07 & -0.27 \\
\hline & & & PV2 & 3.27 & 0.92 & -0.08 & -0.33 \\
\hline & & & PV3 & 3.16 & 0.93 & -0.05 & -0.18 \\
\hline & & & PV4 & 3.04 & 0.95 & 0.02 & -0.17 \\
\hline \multirow{4}{*}{ Innovation value } & \multirow{4}{*}{4.00} & \multirow{4}{*}{0.59} & IV1 & 4.00 & 0.88 & -0.84 & 0.71 \\
\hline & & & IV2 & 3.96 & 0.90 & -0.66 & 0.22 \\
\hline & & & IV3 & 3.92 & 0.91 & -0.57 & -0.11 \\
\hline & & & IV4 & 4.12 & 0.85 & -0.96 & 1.13 \\
\hline \multirow{4}{*}{ Educational value } & \multirow{4}{*}{3.72} & \multirow{4}{*}{0.65} & EdV1 & 3.84 & 0.98 & -0.54 & -0.28 \\
\hline & & & EdV2 & 3.65 & 0.97 & -0.33 & -0.23 \\
\hline & & & EdV3 & 3.82 & 0.95 & -0.61 & 0.07 \\
\hline & & & Edv4 & 3.58 & 1.00 & -0.39 & -0.33 \\
\hline \multirow{4}{*}{ Experience value } & \multirow{4}{*}{3.53} & \multirow{4}{*}{0.60} & ExV1 & 3.45 & 0.91 & -0.27 & -0.23 \\
\hline & & & ExV2 & 3.54 & 0.93 & -0.32 & -0.23 \\
\hline & & & ExV3 & 3.67 & 0.91 & -0.42 & -0.09 \\
\hline & & & ExV4 & 3.44 & 0.94 & 0.00 & -0.36 \\
\hline \multirow{4}{*}{ Purchase Intention } & \multirow{4}{*}{3.65} & \multirow{4}{*}{0.72} & PI1 & 3.62 & 0.96 & -0.54 & 0.28 \\
\hline & & & PI2 & 3.77 & 0.94 & -0.74 & 0.66 \\
\hline & & & PI3 & 3.66 & 0.95 & -0.54 & 0.15 \\
\hline & & & PI4 & 3.54 & 1.00 & -0.45 & -0.14 \\
\hline
\end{tabular}


The absolute values of the skewness of each measurement item were between 0 and 0.96, all of which were less than the cut-off value of three [76]. The absolute values of kurtosis were from 0.07 and 1.13, not exceeding the critical value of 10 [76]. Therefore, the sample data conformed to a normal distribution and were suitable for structural equation model testing.

\subsection{Exploratory Factor Analysis (EFA) and Cronbach's Alpha Analysis}

Before conducting exploratory factor analysis, Bartlett's test of sphericity and the Kaiser-Meyer-Olkin (KMO) measure of sampling adequacy were calculated for all measured items. The results showed a KMO value of 0.930 , which exceeded the recommended value of 0.6 [77], and the Bartlett's test of sphericity was statistically significant (Sig. = 0.000). This confirmed that the factor analysis was appropriate.

In the exploratory factor analysis, the principal components analysis method was used to extract the main factors. The results indicated that the seven factors extracted had a cumulative explained variance of 74.57 percent ( $>60$ percent), which preliminarily validated the conceptual model of museum cultural and creative products (Figure 2). All the items were significant with factor loadings higher than 0.5 and were thus retained for the next round of analysis. Furthermore, the Cronbach's alpha $(\alpha)$ for all questionnaire items was 0.947 , and the Cronbach $\alpha$ coefficients of the seven subscales, namely quality value $(\mathrm{QV})$, social value $(\mathrm{SV})$, price value $(\mathrm{PV})$, innovation value (IV), educational value $(\mathrm{EdV})$, experiential value $(\mathrm{ExV})$, and purchase intention (PI), were as follows: $\alpha_{\mathrm{QV}}=0.845$, $\alpha_{\mathrm{SV}}=0.871, \alpha_{\mathrm{PV}}=0.914, \alpha_{\mathrm{IV}}=0.894, \alpha_{\mathrm{EdV}}=0.845, \alpha_{\mathrm{ExV}}=0.857, \alpha_{\mathrm{PI}}=0.908$. They were all above 0.7 , indicating that the questionnaire had high internal reliability.

\subsection{Confirmatory Factor Analysis (CFA)}

The measurement model fit was assessed by CFA analysis. Five important measures were used to estimate the model fit, namely the square error of approximation (RMSEA), the ratio of the chi-square value to degrees of freedom $\left(\chi^{2} / \mathrm{df}\right)$, Tacker-Lewis index (TLI), normed fit index (NFI), and comparative fit index (CFI). A RMSEA less than 0.08 and a TLI, a NFI, a GFI, and a CFI above 0.90 indicate good model fit, as does a $\chi^{2} / \mathrm{df}$ between 1 and 3 [78]. The results for the measurement model showed that each fit index (RMSEA (0.056), $\chi^{2} / \mathrm{df}(2.066)$, TLI (0.937), NFI (0.900), and CFI (0.945)) reached acceptable levels, indicating a good fit with the collected data.

Item reliability, construct reliability, and average variance extracted were examined with regard to the convergent validity of CFA [79]. As shown in Table 3, all confirmatory factor loadings were larger than 0.6 , indicating item reliability. The construct reliability (CR) values ranged from 0.85 to 0.91 , greater than 0.6 , which is the threshold value of acceptable reliability. The average variance extracted (AVE) reflects the overall amount of variance in the indicators accounted for by a latent construct. The AVEs for the constructs ranged from 0.58 to 0.73 , higher than the cut-off value of 0.5 , indicating all constructs were satisfactory. The convergent validity of the measurement model was good.

In addition, according to Fornell and Larcker [80], if the square root of the AVE is greater than the absolute value of the correlation coefficient between the latent variables, this indicates that discriminant validity is high. As shown in Table 4, by comparing the square root of the AVE with the correlations among the constructs, each construct was more closely related to its own measure than to other constructs, implying that the model had sufficient discriminant validity. 
Table 3. CFA for the measurement model.

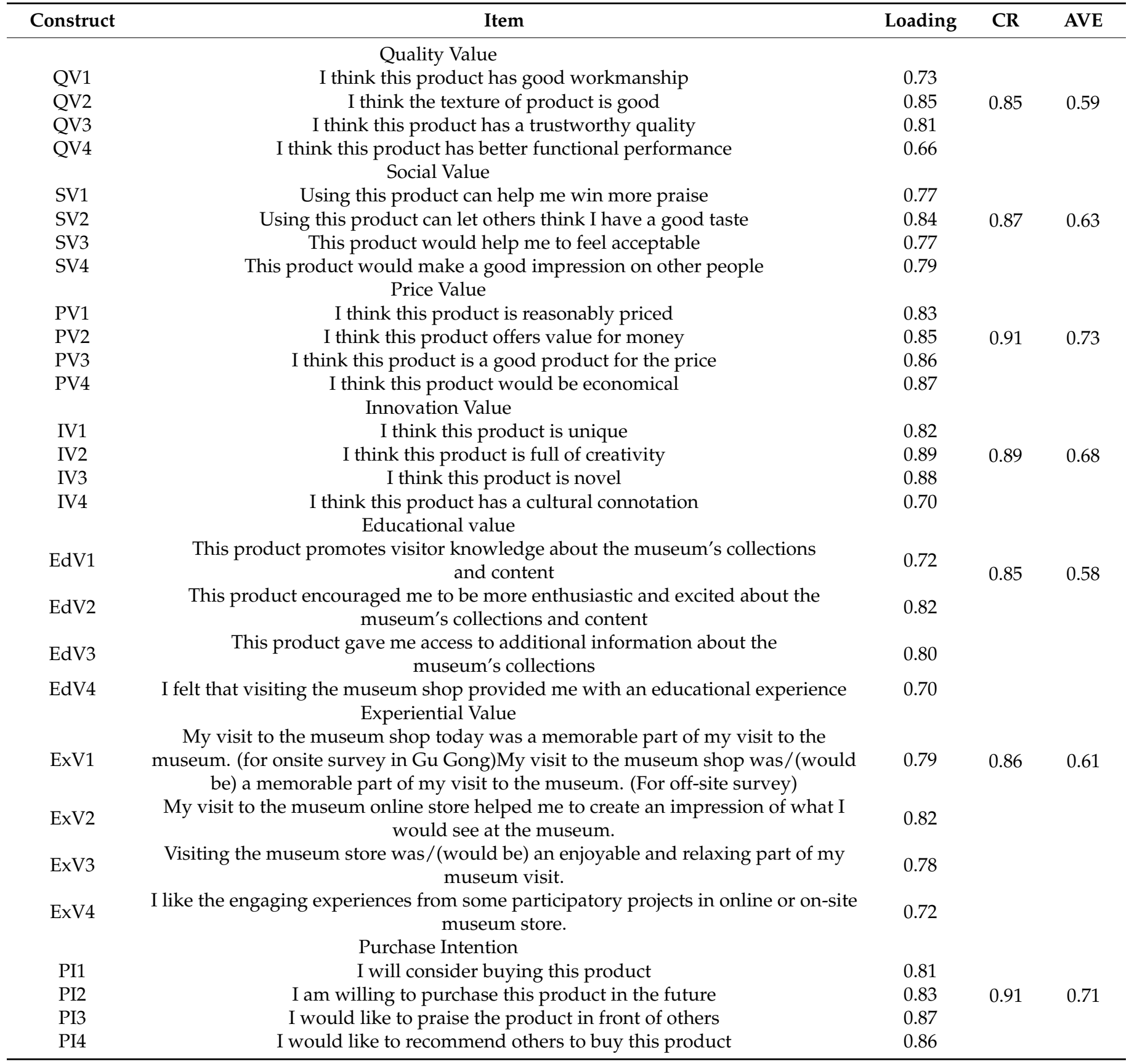

Note: $\mathrm{QV}$ = quality value; $\mathrm{SV}$ = social value; $\mathrm{PV}$ = price value; $\mathrm{IV}$ = innovation value; $\mathrm{EdV}$ = educational value; $\mathrm{ExV}=$ experiential value; $\mathrm{PI}$ $=$ purchase intention.

Table 4. Correlation matrix of constructs.

\begin{tabular}{ccccccccc}
\hline & Mean & QV & SV & PV & IV & EdV & ExV & PI \\
\hline QV & 3.78 & 0.77 & & & & & & \\
SV & 3.12 & 0.55 & 0.79 & & & & & \\
PV & 3.15 & 0.50 & 0.45 & 0.85 & & & & \\
IV & 4.00 & 0.63 & 0.50 & 0.42 & 0.82 & & & \\
EdV & 3.72 & 0.53 & 0.56 & 0.49 & 0.68 & 0.76 & & \\
ExV & 3.53 & 0.45 & 0.58 & 0.49 & 0.58 & 0.72 & 0.78 & \\
PI & 3.65 & 0.51 & 0.52 & 0.47 & 0.69 & 0.64 & 0.70 & 0.84
\end{tabular}

Note: $\mathrm{QV}$ = quality value; $\mathrm{SV}$ = social value; $\mathrm{PV}=$ price value; IV = innovation value; $\mathrm{EdV}=$ educational value $\mathrm{ExV}=$ experiential value; $\mathrm{PI}=$ purchase intention. 


\subsection{Structural Model}

Having established a reliable and valid measurement model, a structural model was used to test the predictive relationships between the constructs of the proposed conceptual model. The simultaneous maximum-likelihood-estimation procedure was employed to examine the hypothesized relationships among quality, social, price, innovation, education, and experience values and purchase intentions. As shown in Table 5 , the root mean square residual (RMR) (0.037), RMSEA (0.056), NFI (0.900), incremental fit index (IFI) (0.946), TLI (0.937), CFI (0.945), parsimonious goodness of fit index (PGFI) (0.709), parsimonious NFI (PNFI) (0.783), and $\chi^{2} / \mathrm{df}(2.066)$ all met acceptable standards. Although the goodness of fit index (GFI) (0.875) and adjusted GFI (AGFI) (0.846) did not meet the standard of 0.9 or higher, they were still at a level of 0.8 or higher recommended by Sengars and Grover [81]. Therefore, this indicated that the structural model had a reasonable explanation of the observed covariance among the constructs.

Table 5. Goodness of fit.

\begin{tabular}{ccc}
\hline Fit Indices & Criteria & Indicators \\
\hline GFI & Absolute index & \\
AGFI & $>0.9$ & 0.875 \\
RMR & $>0.9$ & 0.846 \\
RMSEA & $>0.08$ & 0.037 \\
& $>0.08$ & 0.056 \\
NFI & Relative index & \\
IFI & $>0.9$ & 0.900 \\
TLI & $>0.9$ & 0.946 \\
CFI & $>0.9$ & 0.937 \\
& $>0.9$ & 0.945 \\
PGFI & $>0.5$ & 0.709 \\
PNFI & $>0.5$ & 0.783 \\
$\chi^{2} /$ df & $<3$ & 2.066 \\
\hline
\end{tabular}

\subsection{Hypothesis Tests}

Figure 3 provides details on the parameter estimates for the model, and Table 6 reports the results of the hypotheses tests.

Table 6. Hypothesis tests.

\begin{tabular}{cccc}
\hline Path & Estimate & $\boldsymbol{t}$-Value & Hypothesis Test \\
\hline Quality value $\rightarrow$ Purchase intention & 0.01 & 0.11 & Reject \\
Social value $\rightarrow$ Purchase intention & 0.04 & 0.69 & Reject \\
Price value $\rightarrow$ Purchase intention & 0.07 & 1.42 & Reject \\
Innovation value $\rightarrow$ Purchase intention & 0.39 & $5.21^{* *}$ & Support \\
Educational value $\rightarrow$ Purchase intention & 0.04 & 0.54 & Reject \\
Experiential value $\rightarrow$ Purchase intention & 0.38 & $4.84^{* *}$ & Support \\
${ }_{* *}^{*} p<0.01$. & & &
\end{tabular}

With regard to the three paths between general perceived value drivers and purchase intentions $(\mathrm{H} 1-\mathrm{H} 3)$, the estimation results showed that not all paths were significant $(p>0.01)$. The quality value $(\beta=0.01, t=0.11)$, social value $(\beta=0.04, t=0.69)$, and price value $(\beta=0.07, t=1.42)$ did not have significant influences on purchase intentions. These findings did not support previous studies. This suggested that when travelling, tourist perceptions of the quality, social value, and price value of cultural and creative products may be different from that in daily life, resulting in the insignificant impact of these basic values on purchase intentions. With regard to the three unique and distinctive dimensions of perceived value for cultural and creative products, the research evaluated the drivers' influences on purchase intentions ( $\mathrm{H} 4-\mathrm{H} 6)$. The estimation results showed that innovation 
value $(\beta=0.39, t=5.21)$ and experiential value $(\beta=9.38, t=4.84)$ had significant positive effects on purchase intentions at the level of $p=0.000$. However, educational value did not have a significant influence on purchase intentions $(\beta=0.04, t=0.54)$. A possible explanation for this non-significant effect of educational value on purchase intentions is that the educational mission expressed by the cultural and creative products of the Palace Museum to tourists was not strong enough.

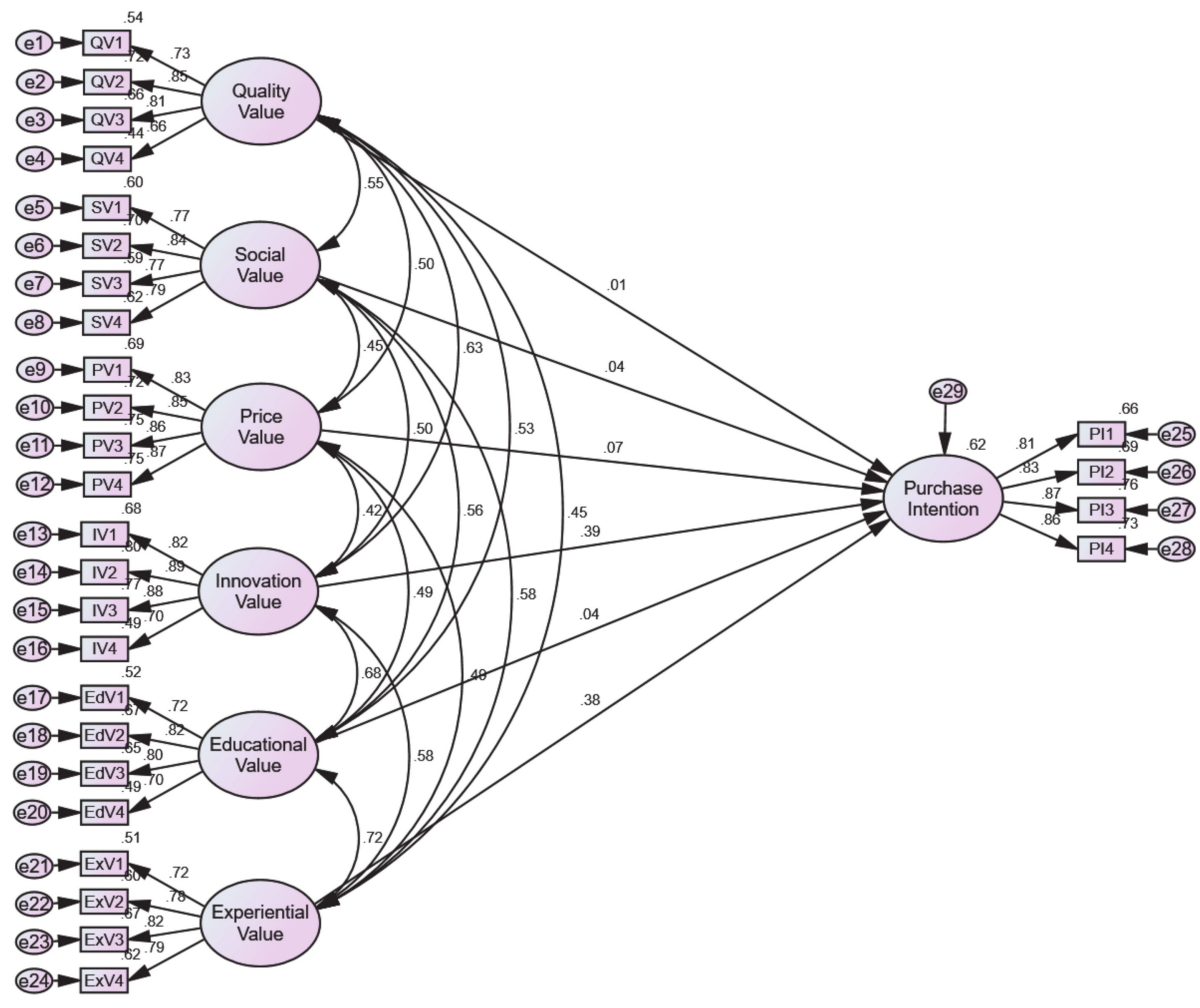

Figure 3. The Estimated Model.

\section{Conclusions and Discussion}

Using a mixed-method approach, the research explored the components of consumers' perceived value of museum cultural and creative products and their impact on purchase intentions. The interview data and the extant literature depict how the six dimensions (educational, experience, innovation, price, quality, and social) of perceived value are fostering the tourists' intentions to buy cultural and creative products in museums. The results from the quantitative data collected from the tourists provided empirical evidence about the antecedents of purchase intentions in museums which was also reflected from the interviews of the museum expert providing cross-validation of each other. Perceived innovation and experiential values are found to have a positive influence on the purchase of museum cultural and creative products, while quality, price, social and educational values are not.

\subsection{Theoretical Implications}

The theoretical model proposed by this research specifies the dimensions (educational, experience, innovation, price, quality, and social) of retail products for sale in museums. The proposed model is derived from the extant studies (e.g., [11,45,51,54,60]). The purpose of Sweeney and Soutar [60]'s work was to measure and confirm consumers' perceived quality, price, social, and emotional values for durable consumer goods. Although these researchers' motivation was to understand and explain the important factors that influenced consumers' intentions to buy durable consumer goods, the model has subsequently been applied in a wide range of fields. For this research, a multidimensional perceived value model 
was proposed and adapted to tourism-oriented museum cultural and creative products. Evidence for the direct effects of quality, price, social, and educational values on purchase intentions was, however, not provided. The reason might be the rather low perceptual level of the quality, social, and prices value the tourists had with museum cultural and creative products in a context of travelling rather than in normal daily life.

The data suggests that perceived innovation and experience values were the two factors driving consumers to purchase museum cultural and creative products. These results support what Booth and Powell [11], Kotler [51], Mottner and Ford [7], Lin et al. [45] and Tu, and Liu and Cui [54] had already observed and implied-the intention to buy cultural and creative products in museums' cultural shops is heavily impacted by the level of innovation and experience values they provide. Although, in general, educational value is important for museums $([11,51])$, this research found that it was not a significant factor causing tourists to buy museum cultural and creative products. The reasons could be that consumers were not fully aware of the Palace Museum's educational mission or the educational functions of products were not apparent at the time of purchase. For instance, some respondents mentioned that they wanted to buy products reflecting the wisdom of the planning of Beijing but could not find anything worth buying apart from some books. Therefore, the Palace Museum must adopt additional measures to transform the value of education into real consumption. In summary, this research confirms that the multiple perceived values of museum cultural and creative products affect purchase intentions in different ways. In general, innovation and experience values are powerful predictive indicators of purchase intentions.

\subsection{Practical Implications}

This research provides critical insights for practitioners and managers by providing the factors of purchase intentions of cultural and creative products in the museum context. Based on this research, practical strategies and approaches can be adopted by museum managers and marketers to enhance innovation and experience values in designing their cultural products.

Much more innovative forms of educational products should be developed and used to strengthen consumers' experiential value, considering that consumers prefer experiential and innovative products. Regarding the content of innovative products, the value and meaning of the Forbidden City as a world heritage cultural site could be fully explored to the public. For instance, the museum could design a game that allows participants to play the roles of the emperor, capital planners, water system planners, or engineers to simulate the site selection and construction process of Dadu in the Yuan Dynasty. Games can be online or virtual, and the derivative peripheral products related to games can be sold both onsite and online.

Being a valuable and innovative way for consumer engagement [82], information communication technologies can be applied by museums to promote visitor experiences ([13,83-85]). Specifically, the following measures can be taken. First, digital products with interactive experience features, such as mobile apps, can be developed based on panorama or VR technology so that visitors can experience the interactive feelings with cultural collections by touching and sliding their phone screens. Second, museums can launch Do-it-Yourself (DIY) programs based on their collections, both online and offline, which would enhance visitors' appreciation of cultural relics. Third, museums should cooperate with schools and other educational institutions to carry out experiential courses, such as craft-making, role-playing, and scenario simulation. Through these interactive and immersive courses, participants can experience and acquire historical and cultural knowledge, and they may then purchase related products, such as handmade items.

In addition, digital platforms can support museums to provide innovative communication methods for visitors, e.g., customization, experimentation, collaborative creation, and gamification [86]. Thus, museum fans and visitors in general should be encouraged to contribute their creative ideas for developing innovative products. For instance, orga- 
nizing creative design competitions or social media topic activities are both good ways. Furthermore, museum product designers can obtain innovative design ideas of products through the following methods, which have already been used by the Palace Museum. First, the color, pattern, image, and language elements of cultural relics can be extracted and combined with daily articles to launch some practical and aesthetic products. For example, the caisson ceiling umbrella is an umbrella designed by extracting the color and pattern symbols of the Palace Museum's caisson ceiling. The Chaozhu earphone is designed based on the bead string used in the formal dress worn by a minister at court in Qing dynasty. Third, hot topics and events can be used to launch derivative products. For example, the Palace Museum and Neiliansheng, a traditional shoe brand, jointly launched a customized pair of cloth shoes with a theme of the popular animated film "Dayu Haitang" when it was released in 2016 in China.

As in the case of the Palace Museum, the application of innovation and digital strategies to cultural and creative products can help cultural institutions survive in harsh environments. At the same time, for the long-term sustainable development of the institutions themselves, sustainable management tools, such as the decision-making management model can be applied to dynamically evaluate and intelligently manage innovative practice [87].

\section{Limitations and Future Research Needs}

Although the relationships between multi-dimensional perceived value and purchase intentions in the museum culture and creative context have been addressed in this research, the research has certain limitations that are important to note and that may point to potential research topics for the future. First, in addition to perceived value, there may be other factors that affect purchase intentions. Past studies have suggested that satisfaction and loyalty as well as brand preference affect purchase intentions ([63,88,89]). More variables should be introduced to expand the research framework of museum cultural and creative products. Second, the influence of population variables and the purchasing environment has not been analyzed in this research. The influence of these two factors on perceived value and purchase intentions needs to be further explored. Third, the sample was mostly composed of people with high educational levels and females. Future research should be expanded to more diverse groups, including non-Chinese international visitors.

Author Contributions: Conceptualization, Z.L. and J.S.; methodology, Z.L. and S.S.; software, Z.L. and S.S.; validation, S.S.; formal analysis, S.S. and Z.L.; investigation, S.S.; resources, Z.L. and S.S.; data curation, S.S. and Z.L.; writing - original draft preparation, E.B., Z.L. and S.S.; writing-review and editing, J.S. and A.M.M.; visualization, Z.L. and S.S.; supervision, J.S.; project administration, J.S. and A.M.M.; All authors have read and agreed to the published version of the manuscript.

Funding: This research received no external funding.

Institutional Review Board Statement: Not applicable.

Informed Consent Statement: Informed consent was obtained from all subjects involved in the study.

Data Availability Statement: Secondary data such as government policies etc. available in a publicly accessible repository.

Conflicts of Interest: The authors declare no conflict of interest.

\section{References}

1. Agostino, D.; Arnaboldi, M.; Lampis, A. Italian state museums during the COVID-19 crisis: From onsite closure to online openness. Mus. Manag. Curatorship 2020, 35, 1-11. [CrossRef]

2. International Council of Museums. ICOM Statutes (24 August 2007). Available online: http://archives.icom.museum/statutes. html\#3 (accessed on 15 July 2019).

3. McTavish, L. Shopping in the museum? Consumer spaces and the redefinition of the Louvre. Cult. Stud. 1998, 12, 168-192. [CrossRef]

4. Tufts, S.; Milne, S. Museums: A supply-side perspective. Ann. Tour. Res. 1999, 26, 613-631. [CrossRef] 
5. McPherson, G. Public memories and private tastes: The shifting definitions of museums and their visitors in the UK. Mus. Manag. Curatorship 2006, 21, 44-57. [CrossRef]

6. Kent, T. The role of the museum shop in extending the visitor experience. Int. J. Nonprofit Volunt. Sect. Mark. 2010, 15, 67-77. [CrossRef]

7. Mottner, S.; Ford, J.B. Measuring nonprofit marketing strategy performance: The case of museum stores. J. Bus. Res. 2005, 58, 829-840. [CrossRef]

8. Du, H.-M.; Zhang, S.-M. The Cloud Design System Building Research of Tourist Souvenirs. In Proceedings of the 2016 International Conference on Service Science, Technology and Engineering (SSTE 2016), Suzhou, China, 14-15 May 2016; pp. 274-281. [CrossRef]

9. Li, F.S.; Ryan, C. Souvenir shopping experiences: A case study of Chinese tourists in North Korea. Tour. Manag. 2018, 64, 142-153. [CrossRef]

10. MacDonald, S.; Silverstone, R. Rewriting the museums' fictions: Taxonomies, stories and readers. Cult. Stud. 1990, 4, 176-191. [CrossRef]

11. Booth, E.; Powell, R. Museums: From cabinets of curiosity to cultural shopping experiences. In Tourism and Culture in the Age of Innovation; Katsoni, V., Ed.; Springer International Publishing: New York, NY, USA, 2016; pp. 131-143.

12. Larkin, J. 'All Museums Will Become Department Stores': The Development and Implications of Retailing at Museums and Heritage Sites. Archaeol. Int. 2016, 19, 109-121. [CrossRef]

13. Pallud, J.; Straub, D.W. Effective website design for experience-influenced environments: The case of high culture museums. Inf. Manag. 2014, 51, 359-373. [CrossRef]

14. Falk, J.; Dierking, L.D. Learning from Museums: Visitor Experiences and the Making of Meaning; Alta Mira Press: Walnut Creek, CA, USA, 2000

15. Tosun, C.; Temizkan, S.P.; Timothy, D.J.; Fyall, A. Tourist shopping experiences and satisfaction. Int. J. Tour. Res. 2007, 9, 87-102. [CrossRef]

16. Timothy, D.J. Shopping Tourism, Retailing and Leisure; Channel View Publications: Clevedon, UK, 2005.

17. National Audit Office. Income Generated by the Museums and Galleries: Report by the Comptroller and Auditor General; National Audit Office: London, UK, 2004.

18. Liu, D. The Palace Museum Revealed Itself! The Revenue of Its Cultural and Creative Products Reached RMB 1.5 Billion Yuan in 2017 (19 February 2019). Available online: http:/ / finance.sina.com.cn/roll/2019-02-19/doc-ihqfskcp6568160.shtml (accessed on 12 July 2019).

19. AliData. 2018 Tmall Cultural and Creative Products Consumption Report (20 May 2019). Available online: https:/ / dt.alibaba. com/page48.htm (accessed on 25 June 2020).

20. UNESCO. Imperial Palaces of the Ming and Qing Dynasties in Beijing and Shenyang. 1987. Available online: https://whc.unesco. org/en/list/439/ (accessed on 25 June 2020).

21. Hou, R.; Deng, H. The Origion and Transition of Beijing City; Yanshan Press: Beijing, China, 1997.

22. Hou, R.; Tang, X. Historical Geography of Beijing City; Yanshan Press: Beijing, China, 2000.

23. The Forbidden City Continues to Open to the Public with New Measures (31 December 2018). Available online: https://www. dpm.org.cn/classify_detail/248512.html (accessed on 12 July 2019).

24. Feng, S. The Aggressive Palace Museum (23 March 2019). Available online: https://mp.weixin.qq.com/s/BdO-MJSwj1zuQyx_ 9SiBbQ (accessed on 12 July 2019).

25. Hui, Z. Shan Jixiang Talks about "Future Forbidden City": Exploration and Thinking of Digital Creativity in the Forbidden City (25 March 2019). Available online: http:/ / www.tripvivid.com/articles/19800 (accessed on 24 June 2020).

26. Belenioti, Z.; Tsourvakas, G.; Vassiliadis, C. A Report on Museum Branding Literature. In Strategic Innovative Marketing; Springer International Publishing: New York, NY, USA, 2017; pp. 229-234.

27. Belenioti, Z.; Vassiliadis, C. Social media impact on NPO brand equity: Conceptualizing the trends and prospects. In Proceedings of the 10th Annual Conference of the EuroMed Academy of Business, Rome, Italy, 13-15 September 2017.

28. Kolb, B. Marketing for Cultural Organisations; Routledge: New York, NY, USA, 2013.

29. Vassiliadis, C.; Belenioti, Z. Museums and cultural heritage via social media: An integrated literature review. Int. Multidiscip. J. Tour. 2017, 12, 97-132.

30. Hankinson, P.; Rochester, C. The face and voice of volunteering: A suitable case for branding? Int. J. Nonprofit Volunt. Sect. Mark. 2005, 10, 93-105. [CrossRef]

31. Stater, K.J. The Impact of Revenue Sources on Marketing Behavior: Examining Web—Promotion and Place-Marketing in Nonprofit Organizations. J. Nonprofit Public Sect. Mark. 2009, 21, 202-224. [CrossRef]

32. Hudson, J. The Branding of Charities. The Routledge Companion to Nonprofit Marketing; Routledge: London, UK, 2007.

33. Kylander, N.; Stone, C. The Role of Brand in the Nonprofit Sector. Stanf. Soc. Innov. Rev. 2012, 10, 35-41.

34. Belenioti, Z.-C.; Tsourvakas, G.; Vassiliadis, C.A. Do Social Media Affect Museums' Brand Equity? An Exploratory Qualitative Study. In Strategic Innovative Marketing and Tourism; Springer International Publishing: New York, NY, USA, 2019 ; pp. 533-540.

35. Belenioti, Z.; Vassiliadis, C. Branding in the new museum era. In Strategic Innovative Marketing, Proceedings of the 4th IC-SIM, Mykonos, Greece, 24-27 September 2015; Kavoura, A., Sakas, D., Tomaras, P., Eds.; Springer: Cham, Switzerland, 2017 ; pp. $115-121$. 
36. Belenioti, Z. A snapshot of Greek social media users. In Proceedings of the "Users across Media" Conference at University of Copenhagen, Copenhagen, Denmark, 6-8 May 2015; pp. 1-15. Available online: http://meaningacrossmedia.mcc.ku.dk/ proceedings/ (accessed on 5 February 2019).

37. Belenioti, Z.C.; Andronikidis, A.I.; Vassiliadis, C. Classifying and profiling social media users: An integrated approach. In Proceedings of the 2nd European Conference on Media, Communication and Film, Brighton, UK, 13-16 July 2015 ; pp. 183-204.

38. Belenioti, Z.C.; Tsourvakas, G.; Vassiliadis, C. Museums Brand Equity and Social Media: Looking into Current Research Insights and Future Research Propositions. In Strategic Innovative Marketing and Tourism; Springer International Publishing: New York, NY, USA, 2019; pp. 1215-1222.

39. Hausmann, A. The importance of word of mouth for museums: An analytical framework. Int. J. Arts Manag. 2012, 14, 32-43.

40. Fletcher, A.; Lee, M.J. Current social media uses and evaluations in American museums. Mus. Manag. Curatorship 2012, 27, 505-521. [CrossRef]

41. Hausmann, A.; Poellmann, L. Using social media for arts marketing: Theoretical analysis and empirical insights for performing arts organizations. Int. Rev. Public Nonprofit Mark. 2013, 10, 143-161. [CrossRef]

42. Li, R.J.; He, M.Q. Rethinking the cultural goods of the museum: From the perspective of cross-border. J. Des. 2009, 14, 69-84.

43. Chiou, S.C.; Wang, Y.C. The example application of genetic algorithm for the framework of cultural and creative brand design in Tamsui Historical Museum. Soft Comput. 2018, 22, 2527-2545. [CrossRef]

44. Huang, M.-H.; Houng, W.; Lin, R. Exploration of the Cultural Product Design of the National Palace Museum from a Qualia Viewpoint. In Proceedings of the International Conference on Internationalization, Design and Global Development, Orlando, FL, USA, 9-14 July 2011; Volume 6775, pp. 65-74.

45. Lin, C.-T.; Lee, C.; Wang, S.-W.; Chen, Y.-H. Using the DEMATEL Method to Explore the Critical Factors That Influence Visitors to Purchase Museum Cultural Products. J. Test. Eval. 2018, 46, 2045-2055. [CrossRef]

46. Wei, M.; Chen, T.; Hsieh, Y. Study of Cultural Creative Merchandises of Museums and Cultural Heritage. In Advances in Graphic Communication, Printing and Packaging; Zhao, P., Ouyang, Y., Xu, M., Yang, L., Ren, Y., Eds.; Springer: Singapore, 2019; Volume 543, pp. $447-451$.

47. Beard, M. Souvenirs of culture: Deciphering (in) the museum. Art Hist. 1992, 15, 505-532. [CrossRef]

48. Poulter, E.K. The real thing? Souvenir objects in the West African collections at the Manchester Museum. J. Mater. Cult. 2011, 16, 265-284. [CrossRef]

49. Trabskaia, I.; Shuliateva, I.; Abushena, R.; Gordin, V.; Dedova, M. City branding and museum souvenirs: Towards improving the St. Petersburg city brand. J. Place Manag. Dev. 2019, 12, 529-544. [CrossRef]

50. Chen, L.Y. The value, design methods and principles of museum cultural and creative products. Cult. Ind. Res. 2016, 3, 144-158.

51. Kotler, N. New ways of experiencing culture: The role of museums and marketing implications. Mus. Manag. Curatorship 2004, 19, 417-425. [CrossRef]

52. Fantoni, S.F.; Jaebker, K.; Leason, T. Participatory Experiences in Art Museums: Lessons from Two Years of Practice (7 February 2014). Available online: https://mw2014.museumsandtheweb.com/paper/participatory-experiences-in-artmuseums-lessons-from-two-years-of-practice/ (accessed on 15 July 2019).

53. Ye, M.; Huang, W.J. Talking about the design ideas of museum cultural creative products based on perceptual consumption psychology. Nat. Sci. Mus. Res. 2016, 1, 113-119.

54. Tu, J.-C.; Liu, L.-X.; Cui, Y. A study on consumers' preferences for the Palace Museum's cultural and creative products from the perspective of cultural sustainability. Sustainability 2019, 11, 3502. [CrossRef]

55. Porter, M.E. Competitive Advantage: Creating and Sustaining Superior Performance; Free Press: New York, NY, USA, 1985.

56. Zeithaml, V.A. Consumer perceptions of price, quality, and value: A means-end model and synthesis of evidence. J. Mark. 1988, 52, 2-22. [CrossRef]

57. Woodruff, R.B. Customer value: The next source for competitive advantage. J. Acad. Mark. Sci. 1997, 25, 139. [CrossRef]

58. Snoj, B.; Korda, A.P.; Mumel, D. The relationships among perceived quality, perceived risk and perceived product value. J. Prod. Brand Manag. 2004, 13, 156-167. [CrossRef]

59. Sheth, J.N.; Newman, B.I.; Gross, B.L. Why we buy what we buy: A theory of consumption values. J. Bus. Res. 1991, 22, 159-170. [CrossRef]

60. Sweeney, J.C.; Soutar, G.N. Consumer perceived value: The development of a multiple item scale. J. Retail. 2001, 77, 203-220. [CrossRef]

61. Sánchez, J.; Callarisa, L.; Rodríguez, R.M.; Moliner, M.A. Perceived value of the purchase of a tourism product. Tour. Manag. 2006, 27, 394-409. [CrossRef]

62. Wang, E.S.-T. Impact of Multiple Perceived Value on Consumers' Brand Preference and Purchase Intention: A Case of Snack Foods. J. Food Prod. Mark. 2010, 16, 386-397. [CrossRef]

63. Al-Sabbahy, H.Z.; Ekinci, Y.; Riley, M.; Miller, G.A.; Hudson, S. An Investigation of Perceived Value Dimensions: Implications for Hospitality Research. J. Travel Res. 2004, 42, 226-234. [CrossRef]

64. Vigneron, F.; Johnson, L.W. Measuring perceptions of brand luxury. J. Brand Manag. 2004, 11, 484-506. [CrossRef]

65. Wang, L.; Zhang, H.M.; Lu, L.; Cai, L.P.; Yang, Z.P. Research on Perceived Value of Tourists in Wetland Parks. Tour. Trib. 2014, 29, 87-96. 
66. Mullet, G.M.; Karson, M.J. Analysis of purchase intent scales weighted by probability of actual purchase. J. Mark. Res. 1985, 22, 93-96. [CrossRef]

67. Rana, S.M.S.; Osman, A.; Othman, Y.H. Factors Affecting Purchase Intention of Customers to Shop at Hypermarkets. Mediterr. J. Soc. Sci. 2015, 6, 429. [CrossRef]

68. Chen, Y.S.; Chang, C.H. Enhance green purchase intentions: The roles of green perceived value, green perceived risk, and green trust. Manag. Decis. 2012, 50, 502-520. [CrossRef]

69. Chen, C.-F.; Chen, F.-S. Experience quality, perceived value, satisfaction and behavioral intentions for heritage tourists. Tour Manag. 2010, 31, 29-35. [CrossRef]

70. Chen, Z.; Dubinsky, A.J. A conceptual model of perceived customer value in e-commerce: A preliminary investigation. Psychol. Mark. 2003, 20, 323-347. [CrossRef]

71. Kuo, Y.-F.; Wu, C.-M.; Deng, W.-J. The relationships among service quality, perceived value, customer satisfaction, and postpurchase intention in mobile value-added services. Comput. Hum. Behav. 2009, 25, 887-896. [CrossRef]

72. Petrick, J.F.; Backman, S.J. An examination of the construct of perceived value for the prediction of golf travelers' intentions to revisit. J. Travel Res. 2002, 41, 38-45. [CrossRef]

73. Wood, C.M.; Scheer, L.K. Incorporating perceived risk into models of consumer deal assessment and purchase intent. Adv. Consum. Res. 1996, 23, 399-404.

74. Weng, J.; Run, E. Consumers' personal values and sales promotion preferences effect on behavioural intention and purchase satisfaction for consumer product. Asia Pac. J. Mark. Logist. 2013, 25, 70-101. [CrossRef]

75. Mathwick, C.; Malhotra, N.; Rigdon, E. Experiential value: Conceptualization, measurement and application in the catalog and Internet shopping environment. J. Retail. 2001, 77, 39-56. [CrossRef]

76. Kline, R.B. Principles and Practice of Structural Equation Modeling; Guilford Press: New York, NY, USA, 1998.

77. Pallant, J. SPSS Survival Manual-A Step by Step Guide to Data Analysis Using SPSS for Windows, 3rd ed.; Open University Press: Maidenhead, UK, 2007.

78. MacCallum, R.C.; Browne, M.W.; Sugawara, H.M. Power analysis and determination of sample size for covariance structure modeling. Methods Psychol. 1996, 1, 130-149. [CrossRef]

79. Hair, J.F.; Anderson, R.E.; Tatham, R.L.; Black, W.C. Multivariate Data Analysis, 6th ed.; Prentice Hall: Upper Saddle River, NJ, USA, 2006.

80. Fornell, C.; Larcker, D.F. Evaluating Structural Equation Models with Unobservable Variables and Measurement Error. J. Mark. Res. 1981, 18, 39-50. [CrossRef]

81. Sengars, A.; Grover, V. Re-Examining Perceived Ease of Use and Usefulness: A Confirmatory Factor Analysis. Manag. Inf. Syst. Q. 1993, 17, 517-525. [CrossRef]

82. De Bernardi, P.; Gilli, M.; Colomba, C. Unlocking museum digital innovation. Are 4.0 Torino museums. In Smart Tourism; Cantino, V., Culasso, F., Racca, G., Eds.; McGraw-Hill: New York, NY, USA, 2018; pp. 453-471.

83. Bannon, L.; Benford, S.; Bowers, J.; Heath, C. Hybrid design creates innovative museum experiences. Commun. ACM 2005, 48, 62-65. [CrossRef]

84. Cuny, C.; Fornerino, M.; Helme-Guizon, A. Can music improve e-behavioral intentions by enhancing consumers' immersion and experience? Inf. Manag. 2015, 52, 1025-1034. [CrossRef]

85. Pallud, J. Impact of interactive technologies on stimulating learning experiences in a museum. Inf. Manag. 2017, 54, 465-478. [CrossRef]

86. Pesce, D.; Neirotti, P.; Paolucci, E. When culture meets digital platforms: Value creation and stakeholders' alignment in big data use. Curr. Issues Tour. 2018, 22, 1883-1903. [CrossRef]

87. Casanovas-Rubio, M.D.M.; Christen, C.; Valarezo, L.M.; Bofill, J.; Filimon, N.; Armengou, J. Decision-Making Tool for Enhancing the Sustainable Management of Cultural Institutions: Season Content Programming at Palau De La Música Catalana. Sustainability 2020, 12, 5785. [CrossRef]

88. Hsu, C.-L.; Chang, K.-C.; Chen, M.-C. The impact of website quality on customer satisfaction and purchase intention: Perceived playfulness and perceived flow as mediators. Inf. Syst. e-Bus. Manag. 2011, 10, 549-570. [CrossRef]

89. Chinomona, R.; Sandada, M. Customer Satisfaction, Trust and Loyalty as Predictors of Customer Intention to Re-Purchase South African Retailing Industry. Mediterr. J. Soc. Sci. 2013, 4, 437. [CrossRef] 